\title{
METHOD FOR FMD VIRUS 146S COMPONENT CONCENTRATION DETERMINATION WITH REAL-TIME REVERSE TRANSCRIPTION - POLYMERASE CHAIN REACTION IN VACCINE RAW MATERIALS
}

\author{
M. I. Doronin ${ }^{1}$, A. M. Timina' ${ }^{2}$, D. A. Lozovoy' ${ }^{3}$, V. A. Starikov' ${ }^{4}$ D. V. Mikhalishin ${ }^{4}$, N. N. Medvedeva ${ }^{6}$, A. V. Borisov ${ }^{7}$ \\ ${ }^{1}$ Researcher, Candidate of Science (Biology), FGBI "ARRIAH", Vladimir, Russia, e-mail: doronin@arriah.ru \\ ${ }^{2}$ Leading Researcher, Candidate of Science (Veterinary Mediciane), FGBI “ARRIAH”, Vladimir, Russia, e-mail: timina@arriah.ru \\ ${ }^{3}$ Director, Candidate of Science (Veterinary Medicine), FGBI “ARRIAH”, Vladimir, Russia, e-mail: lozovoy@arriah.ru \\ ${ }^{4}$ Leading Researcher, Candidate of Science (Veterinary Medicine), FGBI “ARRIAH”, Vladimir, Russia, e-mail: starikov@arriah.ru \\ ${ }^{5}$ Head of Laboratory, Candidate of Science (Veterinary Medicine), FGBI “ARRIAH", Vladimir, Russia, e-mail: mihalishindv@arriah.ru \\ ${ }^{6}$ Biologist, FGBI “ARRIAH", Vladimir, Russia, e-mail: medvedeva@arriah.ru \\ ${ }^{7}$ Leading Researcher, Candidate of Science (Veterinary Medicine), FGBI “ARRIAH", Vladimir, Russia, e-mail:borisov@arriah.ru
}

\section{SUMMARY}

Method for determination of foot-and-mouth disease (FMD) virus 1465 component concentration with real-time reverse transcription - polymerase chain reaction (rtRT-PCR) in vaccine raw materials is developed. Negative regression model of $C_{1465}=\left(30.269-C_{t}\right) / 4.155$ type allowing determination of FMDV 1465 particle concentrations based on the amplification threshold cycle values $\left(C_{t}\right)$ is proposed. It has been experimentally proven that the quantity of the 1465 component determined by the real-time RT-PCR method using developed regression model and contained in the inoculation dose of FMD vaccine confers protection to the vaccinated animals against generalized FMD of A, 0, Asia- 1 types. rtRT-PCR method is highly sensitive and allows rapid and highly reliable estimation of the 1465 antigen concentration in FMD vaccine. The method for 1465 particle quantity determination by real-time RT-PCR using the regression model is reliable and demonstrates high correlation (95.5-99.0\%) with the complement fixation test results.

Key words: foot-and-mouth disease (FMD) virus, concentration of 1465 component, rtRT-PCR, amplification threshold cycle.

\section{INTRODUCTION}

Foot-and-mouth disease is a highly contagious vesicular virus disease of cloven-hooved animals that is classified to transboundary infections $[3,11]$. The agent is a non-enveloped RNA-virus that belongs to Picornavirales order, Aphthovirus genus of Picornaviridae family [11]. FMD virus is highly antigenically variable due to mutations in capsid protein genes and has 7 types and various subtypes [11, 13].

FMD causes huge economic losses associated with costs for the disease eradication and stringent measures imposed on domestic and international trade in animal products. Complex measures for FMD prevention and control include mass immunization of animals as well as control of postvaccinal immunity level $[6,13]$.

FMD virus forms 4 variants of its specific components when it is reproduced in suspension continuous baby hamster kidney cell line (BHK-21/2-17): 146S component (whole particles) containing one viral RNA molecule and 60 polypeptide copies, each is a complex of $\mathrm{VP}_{1}-\mathrm{VP}_{2}-\mathrm{VP}_{3}-$
$\mathrm{VP}_{4}$ proteins; $75 \mathrm{~S}$ particles lacking RNA and comprising 60 copies of $V P_{1}-V P_{3}-V P_{0}$ polypeptide; $12 S$ component consisting of $V P_{1} V P_{2}, V P_{3}$ proteins; $3.85 \mathrm{~S}$ subunits represented by non-structural $V \mathrm{P}_{\mathrm{g}}$ protein $[8,10]$.

Concentration of highly immunogenic and resistant $146 \mathrm{~S}$ particles in raw materials is of great importance for FMD vaccine production [3, 12]. Therefore, each batch of FMD vaccine raw materials is tested by quantitative complement fixation test (CFT) to determine $146 \mathrm{~S} \mathrm{com-}$ ponent concentration. However, this method has some disadvantages: it is labour and time consuming (test duration is at least 2-3 days) especially when many samples are tested simultaneously [1].

Therefore, it is reasonable to propose a real-time reverse transcription - polymerase chain reaction (rtRT-PCR)based method for determination of FMDV whole particle concentrations in vaccine raw materials that is highly sensitive and specific and more rapid that will allow simultaneous testing of several dozens of virus-containing raw 
Table 1

Correlation between FMDV $146 \mathrm{~S}$ component concentrations determined by CFT and amplification threshold cycle values determined by rtRT-PCR $n=3$

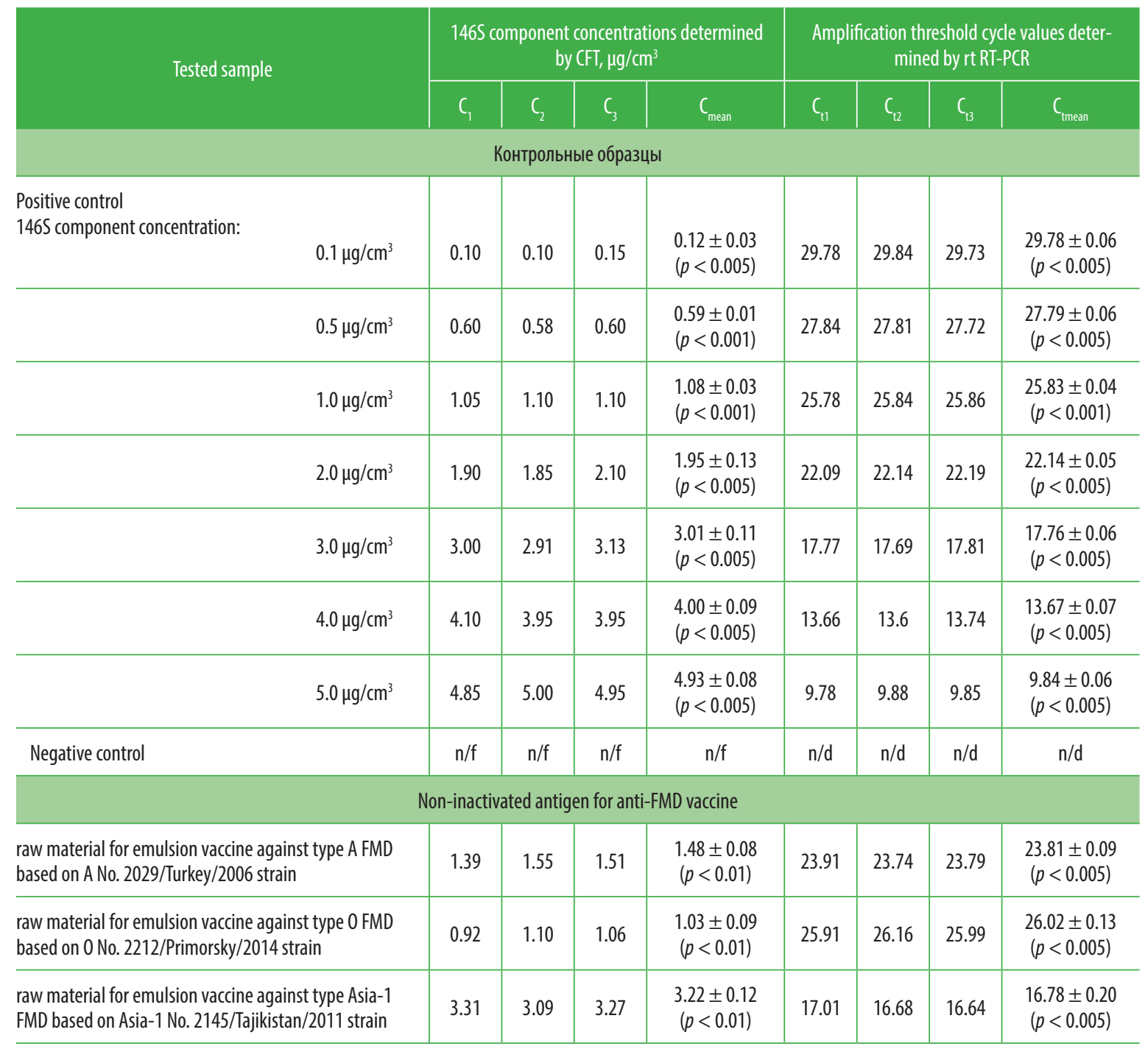

$\mathrm{n} / \mathrm{f}-146 \mathrm{~S}$ component of FMD virus was not found;

$\mathrm{n} / \mathrm{d}-\mathrm{FMD}$ virus genome was not detected.

material samples and reduce testing time to 4 hours [7,9]. Considering rtRT-PCR advantages as compared to CFT a negative linear correlation between FMDV 1465 component quantity in vaccine raw materials and amplification threshold cycle values $\left(C_{t}\right)$ is to be established in the form of regression model. As for rtRT-PCR, $C_{t}$ value depends on FMDV RNA concentration and number of viral RNA copies is proportional to number of $146 \mathrm{~S}$ particles. Experimental demonstration of correlation between rtRT-PCR and CFT results will enable development of rapid and costeffective method for determination of whole virus particle concentrations in vaccine raw material.

The study was aimed at assessment of potential rtRTPCR use for determination of FMDV 1465 component concentration in vaccine raw materials.

\section{MATERIALS AND METHODS}

Virus. Culture FMDV A No. 2029/Turkey/2006, O No. 2212/Primorsky/2014, Asia-1 No. 2145/Tajiki- stan/2011 vaccine strains deposited to the FGBI "ARRIAH" Collection of Microorganism Strains were used. The virus was reproduced in suspension continuous BHK-21/2-17 cell culture.

Complement fixation test (CFT). Quantitative CFT variant with FMDV antigen and strain-specific guinea pig sera against the above-said FMDV strains was used for determination of $146 \mathrm{~S}$ component concentration $\left(\mu \mathrm{g} / \mathrm{cm}^{3}\right)$ [1].

$R N A$ extraction from the vaccine raw materials was performed with commercial RIBO-sorb kit (FBSE "Central Research Institute of Epidemiology" of the Rospotrebnadzor) in accordance with manufacturer's instructions.

$r t R T-P C R$. Real-time RT-PCR was used for detection of FMD virus genome and determination of $146 \mathrm{~S}$ particle concentration in the virus-containing suspension. Primers and TaqMan DNA probe designed for highly conservative segment of FMDV 3D-gene were used for analysis. The reaction results were analyzed using Rotor-Gene 1.8.17.5 software that determines amplification threshold value that is reciprocal to number of viral RNA copies and $146 \mathrm{~S}$ component concentration [4]. 
Vaccines. Three emulsion monovalent ARRIAH-VAC vaccines against type $A, O, A s i a-1$. FMD virus were used. The vaccine against type A FMDV contained $6.15 \pm 0.11 \mu \mathrm{g} /$ dose, vaccine against type O FMDV contained $6.03 \pm 0.12 \mu \mathrm{g} /$ dose and vaccine against Asia-1 FMDV contained $6.43 \pm 0.12 \mu \mathrm{g} /$ dose of $146 \mathrm{~S}$ component as determined by CFT; and rtRT-PCR-determined concentration of $146 \mathrm{~S}$ component was $6.20 \mu \mathrm{g} /$ dose in vaccine against type A FMDV, $6.12 \mu \mathrm{g} /$ dose in vaccine against type O FMDV and $6.50 \mu \mathrm{g} /$ dose in vaccine against Asia-1 FMDV.

Animals. Twenty-one Landrace and Duroc gilts weighing 30-40 kg were used.

Immunization and challenging of animals. All animals were divided into 3 test groups, 5 gilts per group. Animals of test group 1 were immunized with emulsion monovalent vaccine against type A FMD, animals of test group 2 were immunized with the vaccine against type O FMD and animals of test group 3 were immunized with the vaccine against type Asia-1 FMD. Three control groups, 2 animals per group, were formed for type $A, 0$, Asia-1 FMDV, respectively. The non-diluted vaccine was injected intramuscularly at a dose of $2 \mathrm{~cm}^{3}$ in the upper third of neck. Animals of test group 1, test group 2 and test group 3 were challenged with gilt-adapted homologous FMDV A No. 2029/Turkey/2006, O No. 2212/Primorsky/2014 and Asia-1 No. 2145/Tajikistan/2011 strains, respectively. The said virus strains were injected at a dose of $10^{4} \mathrm{ID}_{50} / 0.2 \mathrm{~cm}^{3}$ in tongue mucosa 28 days after immunization. The animals were subjected to postmortem examination 7 days after challenge.

Determination of antibody titres in animal sera after immunization was performed with neutralization test in accordance with approved guidelines [2].

Statistical data processing. Obtained results were processed and arithmetical mean, confidence level for statistical difference between mean values determined with differential Student's-Fischer test as well as determination coefficient were identified [5]. Diagrams were constructed using Microsoft Excel 2010 software application package.

\section{RESULTS AND DISCUSSION}

At the first stage a calibration panel of control positive samples containing amounts of FMDV RNA equivalent to the following $146 \mathrm{~S}$ component concentrations: 0.1 ; $0.5 ; 1.0 ; 2.0 ; 3.0 ; 4.0 ; 5.0 \mu \mathrm{g} / \mathrm{cm}^{3}$ as well as negative control that was BHK-21/2-17 cell suspension not infected with FMDV were prepared to identify correlation between $146 \mathrm{~S}$ component concentrations determined by CFT and amplification threshold cycle values determined with rtRT-PCR. Two specimens were taken from each sample: one - for amplification threshold cycle value $\left(C_{t}\right)$ determination with rtRT-PCR and the other one - for estimation of FMDV 146S component concentration $\left(\mathrm{C}_{1465}\right)$ with CFT. The experiment was repeated thrice. Parallelly determined $146 \mathrm{~S}$ particle concentrations and amplification threshold cycle values were selected based on the analysis results (Table 1).

Table 1 shows that amplification threshold cycle values for all dilutions of FMDV $146 \mathrm{~S}$ component at concentration of $0.1-5.0 \mu \mathrm{g} / \mathrm{cm}^{3}$ were in the range of $29.78 \pm 0.06-9.84 \pm 0.06$, respectively. No FMD virus genome was detected in negative control sample. Based on the obtained data negative linear correlation between $C_{1465}$ and $C_{t}$ was identified as a $C_{1465}=\left(30.269-C_{t}\right) / 4.155$ regression model plotted as linear function in Figure. Actual determination coefficient $\left(R^{2}\right)$ for the said correlation tends

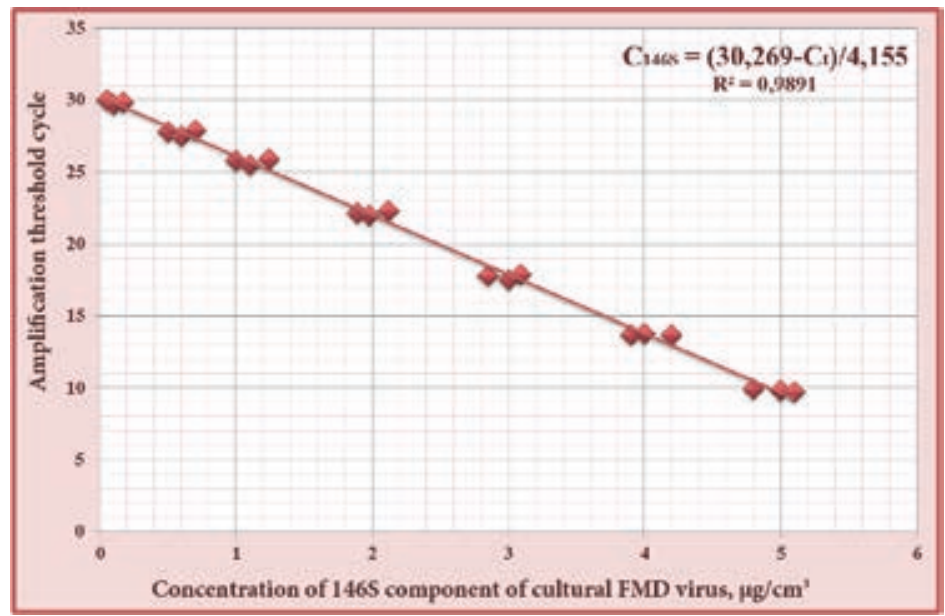

Fig. Graph of correlation between amplification threshold values and cultured FMDV 1465 component concentrations $(n=3)$

to 1 and is 0.9891 that indicates high reliability of the obtained results.

At the next stage proposed regression model was tested by determining $146 \mathrm{~S}$ particle concentrations in non-inactivated raw materials for vaccines against FMDV of three types (A, O, Asia-1) with rtRT-PCR method.

Non-inactivated virus-containing material intended for production of type A FMD vaccine based on A No. 2029/ Turkey/2006 was tested. The specimen was parallelly tested in triplicate with rtRT-PCR and CFT. Obtained results given in Table 1 show that amplification threshold cycle value was $23.81 \pm 0.09$. In accordance with regression model $C_{1465}=\left(30.269-C_{t}\right) / 4.155146 S$ component concentration in the given specimen was $1.55 \pm 0.02 \mu \mathrm{g} / \mathrm{cm}^{3}$ that correlated to the CFT results $\left(1.48 \pm 0.08 \mu \mathrm{g} / \mathrm{cm}^{3}\right)$. In other words, developed model based on rtRT-PCR method allows estimation of $146 \mathrm{~S}$ component quantity in noninactivated raw material for vaccine against type A FMD.

Prepared material was inactivated, concentrated twice and $146 \mathrm{~S}$ antigen quantity was estimated per dose $\left(2 \mathrm{~cm}^{3}\right)$. Test results are given in Table 2 and show that $146 \mathrm{~S} \mathrm{com-}$ ponent quantity in inactivated material theoretically estimated based on rtRT-PCR results considering initial whole virus particle quantity and concentration factor was $6.20 \mu \mathrm{g}$ per dose that correlated with experimental CFT results $(6.15 \pm 0.11 \mu \mathrm{g}$ per dose).

Prepared monovalent emulsion vaccine against type $A$ FMD was used for inoculation of 5 gilts and tested for its immunogenicity according to standard procedure. Neutralizing antibody titre in immunized animals of test group 1 was $6.10 \pm 0.14 \log _{2}$ (Table 2). Animal challenge test results evidences that quantity of immunogenic components contained in a FMD vaccine dose and determined by regression model-rtRT-PCR protects 5 out of $5 \mathrm{immu}$ nized pigs from generalized type A FMD. All control animals demonstrated generalized FMD form.

At the next stage non-inactivated virus-containing material intended for production of type O FMD vaccine based on O No. 2212/Primorsky/2014 was tested with CFT and rtRT-PCR using proposed regression model; $C_{t}$ value for the sample was $26.02 \pm 0.13$ (Table 1). Based on the developed $C_{1465}=\left(30.269-C_{t}\right) / 4.155$ model $146 S$ component concentration was $1.02 \pm 0.03 \mu \mathrm{g} / \mathrm{cm}^{3}$ that was consistent to CFT results $\left(1.03 \pm 0.09 \mu \mathrm{g} / \mathrm{cm}^{3}\right)$. Therefore, proposed 
Table 2

Tests of three inactivated emulsion monovalent type A, 0, Asia-1 FMD vaccines for their immunogenicity $n=5$

\begin{tabular}{|c|c|c|c|c|c|c|}
\hline \multirow[b]{2}{*}{ Group of animals } & \multirow[b]{2}{*}{ Name of vaccine } & \multicolumn{2}{|c|}{$\begin{array}{l}\text { Concentration of FMDV } 1465 \text { component } \\
\text { in a vaccine, } \mu \mathrm{g} / \text { dose }\end{array}$} & \multirow{2}{*}{$\begin{array}{l}\text { Animal } \\
\text { number }\end{array}$} & \multirow{2}{*}{$\begin{array}{l}\text { Anti-FMDV } \\
\text { antibody titre, } \\
\log _{2}\end{array}$} & \multirow{2}{*}{$\begin{array}{l}\text { Presence of } \\
\text { generalized } \\
\text { disease }\end{array}$} \\
\hline & & CFT & $\begin{array}{l}\text { Theoretically } \\
\text { estimated based on } \\
\text { rtRT-PCR results }\end{array}$ & & & \\
\hline \multirow{6}{*}{ Test group №. 1} & \multirow{6}{*}{$\begin{array}{l}\text { Type A FMD vaccine based on } \\
\text { A No. 2029/Turkey/2006 }\end{array}$} & \multirow{6}{*}{$\begin{array}{l}6.15 \pm 0.11 \\
(p<0.010)\end{array}$} & \multirow{6}{*}{6.20} & 1 & 6.00 & - \\
\hline & & & & 2 & 6.25 & - \\
\hline & & & & 3 & 6.00 & - \\
\hline & & & & 4 & 6.25 & - \\
\hline & & & & 5 & 6.00 & - \\
\hline & & & & $M \pm m$ & $\begin{array}{l}6.10 \pm 0.14 \\
(p<0.010)\end{array}$ & \\
\hline \multirow{2}{*}{ Control group №. 1} & \multirow{2}{*}{ not immunized } & \multirow{2}{*}{-} & \multirow{2}{*}{-} & 6 & $<0.5$ & + \\
\hline & & & & 7 & $<0.5$ & + \\
\hline \multirow{6}{*}{ Test group №. 2} & \multirow{6}{*}{$\begin{array}{l}\text { Type O FMD vaccine based on } \\
0 \text { No. 2212/Primorsky/2014 }\end{array}$} & \multirow{6}{*}{$\begin{array}{l}6.03 \pm 0.12 \\
(p<0.010)\end{array}$} & \multirow{6}{*}{6.12} & 8 & 6.25 & - \\
\hline & & & & 9 & 6.00 & - \\
\hline & & & & 10 & 5.75 & - \\
\hline & & & & 11 & 6.00 & - \\
\hline & & & & 12 & 5.75 & - \\
\hline & & & & $M \pm m$ & $\begin{array}{l}5.95 \pm 0.21 \\
(p<0.010)\end{array}$ & \\
\hline \multirow{2}{*}{ Control group No. 2} & \multirow{2}{*}{ not immunized } & \multirow{2}{*}{-} & \multirow{2}{*}{-} & 13 & $<0.5$ & + \\
\hline & & & & 14 & $<0.5$ & + \\
\hline \multirow{6}{*}{ Test group No. 3} & \multirow{6}{*}{$\begin{array}{c}\text { Type Asia-1 FMD vaccine } \\
\text { based on } \\
\text { Asia-1 No. 2145/Tajikistan/2011 }\end{array}$} & \multirow{6}{*}{$\begin{array}{l}6.43 \pm 0.12 \\
(p<0.010)\end{array}$} & \multirow{6}{*}{6.50} & 15 & 6.25 & - \\
\hline & & & & 16 & 6.25 & - \\
\hline & & & & 17 & 6.00 & - \\
\hline & & & & 18 & 6.50 & - \\
\hline & & & & 19 & 6.25 & - \\
\hline & & & & $M \pm m$ & $\begin{array}{l}6.25 \pm 0.18 \\
(p<0.010)\end{array}$ & \\
\hline \multirow{2}{*}{ Control group №. 3} & \multirow{2}{*}{ not immunized } & \multirow{2}{*}{-} & \multirow{2}{*}{-} & 20 & $<0.5$ & + \\
\hline & & & & 21 & $<0.5$ & + \\
\hline
\end{tabular}

Antibody titres in sera of animals immunized with not-diluted FMD vaccine are indicated.

model based on rtRT-PCR allows estimation of $146 \mathrm{~S}$ component quantity in non-inactivated antigen intended for type O FMD vaccine production.

Prepared material was inactivated, concentrated thrice and 1465 antigen quantity was estimated in a dose of $2 \mathrm{~cm}^{3}$. Test results are given in Table 2 and show that quantity of $146 \mathrm{~S}$ component in inactivated material theoretically estimated based on rtRT-PCR results considering initial whole virus particle quantity and concentration fac- tor was $6.12 \mu \mathrm{g}$ per dose that correlated with CFT results $(6.03 \pm 0.12 \mu \mathrm{g}$ per dose).

Prepared emulsion monovalent vaccine against type O FMD was used for inoculation of 5 pigs. Neutralizing antibody titre in immunized animals of test group 2 was $5.95 \pm 0.21 \log _{2}$ (Table 2). Results of animal challenge test evidenced that quantity of immunogenic components contained in a FMD vaccine dose and determined by rtRT-PCR protected 5 out of 5 immunized pigs from 
generalized type O FMD. All control animals demonstrated generalized FMD.

Then, non-inactivated virus-containing material in tended for production of type Asia-1 FMD vaccine based on Asia-1No. 2145/Tajikistan/2011 was tested with CFT and rtRT-PCR using proposed regression model. Amplification threshold value $\left(C_{t}\right)$ for the sample was $16.78 \pm 0.20$ (Table 1 ). According to developed $C_{1465}=\left(30.269-C_{t}\right) / 4.155$ model $146 \mathrm{~S}$ component concentration was $3.25 \pm 0.05 \mu \mathrm{g} / \mathrm{cm}^{3}$ that was consistent to CFT results $\left(3.22 \pm 0.12 \mu \mathrm{g} / \mathrm{cm}^{3}\right)$. Thus, proposed model based on rtRT-PCR method allows estimation of $146 \mathrm{~S}$ component quantity in non-inactivated raw materials intended for type Asia-1 FMD vaccine production.

Prepared material was inactivated and 1465 antigen quantity was estimated in a dose of $2 \mathrm{~cm}^{3}$. Test results are given in Table 2 and show that quantity of $146 \mathrm{~S} \mathrm{com-}$ ponent in inactivated material theoretically estimated based on rtRT-PCR results considering initial whole virus particles content and concentration factor was $6.50 \mu \mathrm{g}$ per dose that correlated with CFT results $(6.43 \pm 0.12 \mu \mathrm{g}$ per dose).

Prepared emulsion monovalent vaccine was used for inoculation of 5 gilts. Neutralizing antibody titre in immunized animals of test group 3 was $6.25 \pm 0.18 \log _{2}$ (Table 2). Results of animal challenge test evidenced that regression-model-rtRT-PCR-determined quantity of immunogenic components contained in a FMD vaccine dose protected 5 out of 5 immunized pigs from generalized type Asia-1 FMD. All control animals demonstrated generalized FMD.

Thus, rtRT-PCR using $C_{1465}=\left(30.269-C_{t}\right) / 4.155$ regres sion model is a reliable and rapid method for $146 \mathrm{~S} \mathrm{com}$ ponent concentration determination. Test system for detection of vaccine FMDV strains was highly sensitive and demonstrated high correlation (95.5-99.0\%) with CFT results.

\section{CONCLUSION}

New approach to the determination of $146 \mathrm{~S}$ component concentration with rtRT-PCR method and regression model developed based on the said method in raw materials for vaccines against FMD was proposed. Based on CFT and rt RT-PCR results, negative correlation between 1465 component quantity and amplification threshold value was identified in the form of regression and plotted as a linear function graph, $C_{1465}=\left(30.269-C_{t}\right) / 4.155$. As for rtRT-PCR, threshold value depends on FMDV RNA concentration and number of viral RNA copies is proportional to $146 \mathrm{~S}$ component content. Experimental evidence of correlation between CFT and rtRT-PCR results allowed development of rapid and cost-effective method for determination of whole virus particle concentration in vaccine raw materials.

The testing indicated that $146 \mathrm{~S}$ component quantity determined with rtRT-PCR using proposed regression model and contained in an inoculation dose of FMD vaccine protected vaccinated animals from generalized type A, O, Asia-1 FMD.
rtRT-PCR method is highly sensitive and allows rapid and highly reliable determination of $146 \mathrm{~S}$ antigen concentration in FMD vaccine. Proposed method for $146 \mathrm{~S}$ particle quantity determination is reliable and demonstrates high correlation (95.5-99.0\%) with CFT results.

It is shown that the said method can be used for determination of cultural FMDV 1465 component quantity in vaccine raw material.

\section{REFERNCES}

1. Bondarenko A. F. Qualitative and quantitative immunochemical assay of virus proteins [Kachestvennyj I kolichestvennyj immunohimicheskij analiz virusnyh belkov]. Suzdal, 1994 (in Russian).

2. Methodical instructions on neutralization test procedure for determination of immune status of animals with regard to FMD [Metodicheskie ukazanija po postanovke reakcii nejtralizacii dlja opredelenija immunnogo statusa zhivotnyh pri jashhure]: approved by USSR Ministry of Agriculture on 26.12.1983 (in Russian).

3. Ponomaryov A. P., Uzyumov V. L., Gruzdev K. N. Foot-andmouth disease virus: structure, biological and physical and chemical properties [Virus jashhura: struktura, biologicheskie i fizikohimicheskie svojstva]. Vladimir: Foliant, 2006 (in Russian).

4. Lozovoy D. A. , Shishkova A. A., Mikhalishin D. V. et al. Realtime RT-PCR for determination of concentration of $146 \mathrm{~S} \mathrm{com-}$ ponent of FMD virus types O/Saudi Arabia and Asia-1/Shamir in semi-finished vaccine [Primenenie OT-PCR-RV dlya opredeleniya koncentracii $146 \mathrm{~S}$ komponenta virusa yashchura tipov O/ Saudovskaya Araviya i Asia-1/Shamir v polufabrikate vakciny]. Veterinariya. 2017; 6: 57-61 (in Russian).

5. Rumyantzev P. O., Sayenko V. A., Rumyantzeva U. V., Chekin S. Yu. Statistical analysis methods in clinical practice [Statisticheskie metody analiza v klinicheskoj praktike]. Obninsk: GU MRRC RAMS. URL: http://www.kantiana.ru/medicinal/help/StatMethodslnClinics.pdf (in Russian).

6. Annual OIE/FAO FMD Reference Laboratory Network Report. Pirbright, 2007. URL: http://www.wrlfmd.org/ref_labs/ fmd_ref_lab_reports.htm.

7. Shaw A. E., Reid S. M., King D. P. et al. Enhanced laboratory diagnosis of foot and mouth disease by real-time polymerase chain reaction. Rev. Sci. Tech. OIE. 2004; 23 (3): 1003-1009.

8. Gartwright B., Brown F. Chapman W. G. Serological and immunological relationships between the $146 \mathrm{~S}$ and $12 \mathrm{~S}$ particles of foot-and-mouth disease virus. J. Gen. Virol. 1980; 50: 369-375.

9. Shaw A., Reid S. M., Ebert K. et al. Implementation of a onestep real-time RT-PCR protocol for diagnosis of foot-and-mouth disease. J. Virol. Methods. 2007; 143(1): 81-85. https://doi. org/10.1016/j.jviromet.2007.02.009.

10. Lubroth J., Rodriguez L., Dekker A. Vesicular diseases. Diseases of Swine. ed. B. E. Straw, J. J. Zimmerman, S. D'Allaire, D. J. Taylor. $9^{\text {th }}$ ed. Ames, lowa; 2006: 517-536.

11. Manual of Diagnostic Tests and Vaccines for Terrestrial Animals.Vol. 1. $7^{\text {th }}$ ed. Paris, France: OIE; 2012; Chapter 2.1.5: 166-169.

12. Alexandersen S., Zhang Z., Donaldson A. I., Garland A. J. M. The pathogenesis and diagnosis of foot-and-mouth disease. J. Comp. Path. 2003; 129: 1-36. DOI: 10.1016/S00219975(03)00041-0.

13. Wernike K., Beer M., Hoffmann B. Rapid detection of footand-mouth disease virus, influenza $A$ virus and classical swine fever virus by high-speed real-time RT-PCR. J. Virol. Methods. 2013: 193(1): 50-54. DOI: 10.1016/j.jviromet.2013.05.005.

Submitted on 20.03.18 Approved for publication on 19.04.18 